\title{
Importance of Choline as Essential Nutrient and Its Role in Prevention of Various Toxicities
}

\section{Somava Biswas, Sarbani Giri}

Department of Life Science and Bioinformatics, Assam University, Silchar, India Received November 2, 2014; Accepted March 12, 2015.

Key words: Choline - DNA repair - Fetotoxicity - Neurotoxicity - Neural tube defect - Antioxidant

\begin{abstract}
Choline is a water-soluble essential nutrient included as a member of the vitamin B12 group owing to its structural similarities with that of the other members of the group. Its roles and functions, however, extend much wider than that of the vitamins with which it is grouped. Choline is vital for maintenance of various key metabolic processes which play a role in the prevention or progression of various health impairments. The occurrence of diseases like neural tube defect (NTD) and Alzheimer's is prevented by the metabolic role of choline. It is also indispensable for mitigation of various forms of toxic contamination. While adequate level of choline in the body is essential, an excess of choline can result in various forms of disorder. To maintain the optimal level of choline in the body can be a challenge. The vital roles played by choline together with the range of contradictions and problems that choline presents make choline an interesting area of study. This paper attempts to summarize and review some recent publications on choline that have opened up new prospect in understanding the multiple role played by choline and in throwing light on the role played by this wonder essential nutrient in mitigating various forms of toxic contamination.
\end{abstract}

Mailing Address: Prof. Sarbani Giri, Department of Life Science and Bioinformatics, Assam University, Silchar-788011, India; e-mail: girisarbani@yahoo.com 


\section{Introduction}

Choline (trimethyl-beta-hydroxyethylammonium) (Figure 1) is a dietary component that is crucial for normal functioning of all cells (Zeisel and Blusztajn, 1994). It was discovered by Andreas Strecker in 1862, but was officially recognized as an essential nutrient by the US Institute of Medicine's Food and Nutrition Board (Food and Nutrition Board, 1998). Choline is a quaternary ammonium compound that lacks ester bond and contains three methyl groups which are a vital requirement for an array of metabolic reactions.

Though choline has often been clubbed with vitamin B12 group, its functions however, suggest that it is more than just another vitamin. Choline in the diet is available as free choline or is bound as esters such as phosphocholine (Pho), glycerophosphocholine (GPCho), sphingomyelin (SM) or phosphatidylcholine (PtdCho). From these choline esters, choline is freed by pancreatic enzymes. Dietary choline from a variety of choline containing foods is absorbed by the intestine and uptake is mediated by choline transporters. The fate of choline is conversion into PtdCho (also known as lecithin), which occurs in all nucleated cells ( $\mathrm{Li}$ and Vance, 2008). PtdCho is the predominant phospholipid (>50\%) in most mammalian membranes (Zeisel, 2006a). Choline is absorbed in small intestine. Free choline enters the portal circulation and is mostly taken up by the liver (Le Kim and Betzing, 1976). Lipid soluble PtdCho and SM enter via lymph and bypass the liver.Therefore, different forms of choline could have different bioavailability (Cheng et al., 1996). Betaine, a choline derivative, plays an important role in donation of methyl groups to homocysteine to form the essential amino acid methionine (Zeisel et al., 2003). Choline uptake by liver, kidney, mammary gland, placenta and brain is of special importance. Choline and choline containing compounds are crucial for normal sustenance of life. Choline or its metabolites are important for the structural integrity of cell membranes, methyl-metabolism, transmembrane signalling, lipid and cholesterol transport, metabolism and cholinergic neurotransmission and therefore it is vital during critical periods in brain development.

Choline was added to the list of essential nutrients only in recently. In 1998, based on the contemporary research studies, the US Institute of Medicine's Food and Nutrition Board, recognized that for the maintenance of normal health,

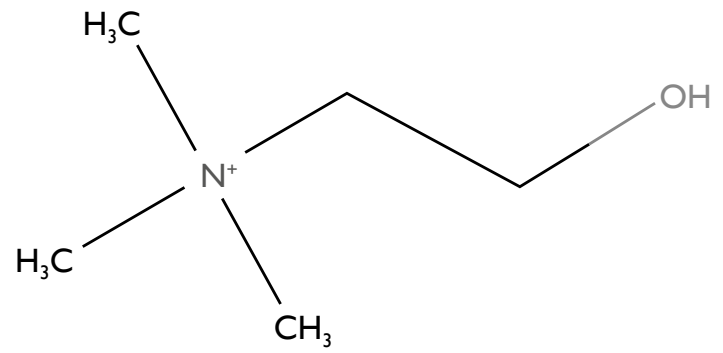

Figure 1 - Chemical structure of choline.

Biswas S.; Giri S. 
humans needed to obtain choline from the diet and issued guidelines for its daily intake. Choline is found in a wide variety of foods, mainly in the form of phosphatidylcholine, which is often called lecithin. Among the most concentrated sources of dietary choline are egg yolk and offal, beef, nuts, leafy greens, legumes, seed oils, grain germs, and dairy products (Shronts, 1997). However, choline can also be synthesized de novo.

The liver is the primary site for endogenous synthesis of choline. The only other source of choline apart from normal diet is from the de novo biosynthesis of phosphatidylcholine (PtdCho). Phosphatidylethanolamine $\mathrm{N}$-methyltransferase (PEMT) activity catalyses the synthesis of PtdCho by the sequential methylation of phosphatidylethanolamine (PtdEtn), using S-adenosylmethionine (AdoMet) as a methyl donor and forms a new choline moiety (Blusztajn et al., 1985).

Several factors such as gender, menopausal status, pregnancy, lactation and genetic mutation affect choline requirement of an individual and de novo synthesis of choline alone fails to meet all human requirements for choline; as a result the recommended adequate intake (Al) for choline has been set at $425 \mathrm{mg} /$ day for women, $450 \mathrm{mg} /$ day for pregnant women, $550 \mathrm{mg} /$ day for men and lactating women as well (Food and Nutrition Board, 1998).

Choline requirement is diminished in premenopausal women because estrogen induces PEMT (Resseguie et al., 2007), the gene in liver enabling endogenous biosynthesis of choline moiety. But many women have single nucleotide polymorphism (SNPs) in the PEMT gene that repeals estrogen-induction of endogenous synthesis (Resseguie et al., 2011) and these women, therefore, require dietary choline just as men do. Thus genetic variance can have effects on choline requirement. Notably, the adequate intake of choline is increased for pregnant and breastfeeding women to satisfy the needs of the fetus and the baby whose choline is supplied via placenta and milk (Zeisel et al., 1986). Also, many of the foods that have high choline content are also high in fats or cholesterol (e.g. eggs). As a result, many people are decreasing their intake of these foods leading to a situation where only a few people today adhere to a diet that meets the recommended choline levels (Food and Nutrition Board, 1998; Jensen et al., 2007).

The reasons mentioned above have resulted in an increasing population with a choline deficient diet which ultimately impedes many normal physiological processes as well as causes a diverse group of pathological processes. In most mammals, prolonged (weeks to months) ingestion of a diet deficient in choline leads to consequences that include hepatic, renal, pancreatic, memory and growth disorders.

However, excess choline intake has detrimental effect in human too. Choline doses that are of magnitude greater than estimated intake from food have been associated with body odor, sweating, salivation, vomiting, gastrointestinal effects, hypotension and hepatotoxicity in humans (LSRO/FASEB, 1981). These apparently contradictory facts about choline, makes its maintenance in the body a challenge. 
In view of the importance of choline as a nutrient it is of utmost importance to review the protective action of choline against genotoxicity, neurotoxicity, fetotoxicity and antioxidative potentials. This review summarizes some current literature findings on the effects of choline in mitigating various toxicity targeting DNA and repair system, neurons, development and fetotoxicity.

\section{Methodology of literature sources selection}

The Tables in this review contain the summary of original research articles, casecontrol and cohort or cross sectional studies published between 2003 and 2013. A literature search was undertaken using Science Direct, PubMed and Google using specific key words. Title and abstracts were read and inclusion/exclusion being decided according to the key words which included choline along with toxicity, genotoxicity, DNA, DNA damage, apoptosis, teratogenicity, maternal health, fetal alcohol syndrome, pregnancy, antioxidant properties, neurotoxicity, neural tube defect, neuroprotection. All the abstracts were read to decide on the inclusion criteria. Studies were included based on the following parameters: i) if the focus was on relevant outcomes i.e. role of choline in mitigating genotoxicity, neurotoxicity, fetotoxicity and antioxidative potentials etc., ii) if the articles were in English.

Studies were excluded if: i) only abstract was available, ii) primary emphasis were on other one carbon nutrients like folate, vitamin B6, vitamin B12, methionine and betaine, iii) focus laid on role of choline in methionine formation via folate metabolism.

\section{Review}

Choline: its role in DNA damage and repair

Choline deficiency has been associated with DNA damage (Table 1). DNA methylation is influenced by choline that ultimately influences genomic stability (Loughery et al., 2011) by altering gene expression for critical genes involved in DNA mismatch repair, resulting in increased mutation rates. Steven H. Zeisel (2012) summarized that choline deficiency increases leakage of reactive oxygen species from mitochondria which is due to altered mitochondrial membrane composition and enhanced fatty acid oxidation. Choline deficiency impairs folate metabolism since the metabolic pathways of these two have a closely knit pathway of metabolism, resulting in decreased thymidylate synthesis and increased uracil misincorporation into DNA, with strand breaks resulting during error-prone repair attempts.

\section{Choline and neurotoxicity}

A number of researches conducted since 1980s have proved that choline accelerates the synthesis and release of acetylcholine in nerve cells, which is one of the principal neurotransmitters (Haubrich et al., 1974; Cohen and Wurtman, 1975; 


\section{Table 1 - Some recent research publications showing choline deficiency association with DNA repair in various test systems}

\begin{tabular}{llll}
\hline Sl. no. & Test system & Observed effects & References \\
\hline 1. & Rats & $\begin{array}{l}\text { Oxidative damage to DNA by formation of apurinic/ } \\
\text { apyrimidinic sites and Ogg1-sensitive sites in DNA } \\
\text { build up due to choline deprivation. }\end{array}$ & $\begin{array}{l}\text { Powell et al. } \\
\text { (2005) }\end{array}$ \\
\hline 2. & Human & $\begin{array}{l}\text { Choline deficiency in humans is associated } \\
\text { with significant damage to DNA and with apoptosis } \\
\text { in peripheral lymphocytes. }\end{array}$ & $\begin{array}{l}\text { da Costa } \\
\text { et al. (2006) }\end{array}$ \\
\hline 3. & Male Sprague- & $\begin{array}{l}\text { Choline is an important methyl donor and is involved } \\
\text { in more than 150 one-carbon transfer reactions } \\
\text { including DNA repair and DNA methylation. }\end{array}$ & $\begin{array}{l}\text { Shinohara } \\
\text { et al. (2006) }\end{array}$ \\
\hline 4. & $\begin{array}{l}\text { In vivo (male } \\
\text { weaning Fisher } \\
\text { 344 (F344) rats) }\end{array}$ & $\begin{array}{l}\text { Choline deficiency is correlated with the silencing } \\
\text { of several tumor suppressor genes responsible } \\
\text { for DNA repair. }\end{array}$ & $\begin{array}{l}\text { Pogribny et al. } \\
\text { (2009) }\end{array}$ \\
\hline In ovo (chicken & $\begin{array}{l}\text { Choline influences histone methylation, } \\
\text { which in turn is important for the activation } \\
\text { DT40 model } \\
\text { system) }\end{array}$ & $\begin{array}{l}\text { of DNA damage response pathways that consist } \\
\text { and repair DNA damage before the cell divides. }\end{array}$ & et al. (2011) \\
& & & \\
\hline
\end{tabular}

Wecker, 1986; Zeisel, 2006a). From diminishing memory loss to preventing neural tube defects, which are a group of congenital malformations, choline plays a crucial role in combating neurotoxicity (Table 2). Though the etiology of Alzheimer's disease is unknown, postmortem studies of brain samples from Alzheimer's disease patients showed lower levels of acetylcholine (Nitsch et al., 1992). In a review, Zeisel (2006b) observes that dietary intake of choline by a pregnant mother and later by the infant directly influences brain development and results in permanent changes in brain function including memory enhancement and learning functions. Experiments with animal models testify that choline supplementation during neonatal period prevents memory decline due to age (Meck and Williams, 2003) and decreases apoptosis rate in hippocampus of fetus whose mothers consumed high choline diets (Craciunescu et al., 2003). In a review Ziesel and da Costa (2009) highlights recent studies which show that choline supplementation during critical periods of neonatal development can have long-term beneficial effects on memory. The mechanism whereby choline supplementation in mothers results in a permanent change in memory of their offspring is not clear. It was assumed that increased brain choline results in subsequent increase in acetylcholine release. However, further investigations proved that choline supplementation to dams results in significantly greater accumulation of phosphocholine and betaine in fetal brain as compared to fetuses without choline exposure (Garner et al., 1995). Although there are sufficient data with animal models indicating that choline is a 

Table 2 - Some recent articles showing choline deficiency association
with neuronal development in various test systems

\begin{tabular}{|c|c|c|c|}
\hline SI. no. & Test system & Observed effects & References \\
\hline 1. & $\begin{array}{l}\text { In vivo (mice } \\
\text { model) }\end{array}$ & $\begin{array}{l}\text { Improvement of the memory and cognitive } \\
\text { dysfunction in Alzheimer's disease are observed } \\
\text { on choline acetyltransferase supplementation. }\end{array}$ & $\begin{array}{l}\text { Fu et al. } \\
(2004)\end{array}$ \\
\hline 2. & $\begin{array}{l}\text { Sprague-Dawley } \\
\text { albino rats }\end{array}$ & $\begin{array}{l}\text { Choline supplementation during critical period of } \\
\text { fetal development alters brain morphology including } \\
\text { structure and function of hippocampal pyramidal } \\
\text { cells, larger soma size and increase in number } \\
\text { of primary and secondary dendritic branches. }\end{array}$ & $\begin{array}{l}\text { Li et al. } \\
(2004)\end{array}$ \\
\hline 3. & $\begin{array}{l}\text { Human female } \\
\text { (population based } \\
\text { case control study) }\end{array}$ & $\begin{array}{l}\text { Deficient maternal dietary intake of choline during } \\
\text { pregnancy in humans may lead to an increased risk } \\
\text { of having a baby with a neural tube defect. }\end{array}$ & $\begin{array}{l}\text { Shaw et al. } \\
(2004)\end{array}$ \\
\hline 4. & $\begin{array}{l}\text { Female Sprague- } \\
\text { Dawley rats }\end{array}$ & $\begin{array}{l}\text { Sensory inhibition gets reduced with gestational } \\
\text { choline deficiency. }\end{array}$ & $\begin{array}{l}\text { Stevens } \\
\text { et al. (2008) }\end{array}$ \\
\hline 5. & $\begin{array}{l}\text { In ovo (chick } \\
\text { embryo) }\end{array}$ & $\begin{array}{l}\text { Choline at low dose }(25 \mu g / \mu l) \text { protected against } \\
\text { sodium-arsenite induced NTDs in chick embryos by } \\
\text { reversed DNA hypomethylation and cell apoptosis. }\end{array}$ & $\begin{array}{l}\text { Song et al. } \\
(2012)\end{array}$ \\
\hline 6. & Female rats & $\begin{array}{l}\text { Supplemental dietary choline, when received during } \\
\text { development, has anxiolytic effects and may inoculate } \\
\text { an individual against stress and psychological } \\
\text { disorders like depression. }\end{array}$ & $\begin{array}{l}\text { Glenn et al. } \\
(2012)\end{array}$ \\
\hline
\end{tabular}

necessary nutrient in reducing cognitive decline and it aids in brain hippocampal development and that choline supplementation during pregnancy results in multiple modifications in the patterns of gene expression known to influence learning and memory, yet there are insufficient human studies to confirm the same (Mellott et al., 2007). Also, several studies hypothesize that choline may play the protective role against neural tube defects (NTDS) by contributing methyl groups through betaine and lowering homocysteine concentration.

Choline and teratogenicity/fetotoxicity

Maternal nutrition is important for normal human development and in particular the supply of methyl groups is vital at all stages from conception to early infancy. Adequate maternal choline intake is vital to a healthy pregnancy. A number of studies have demonstrated the protective role of maternal choline supplementation (Table 3). Maternal choline intake is critical not only for proper fetal brain development, but also for maintaining normal maternal homocysteine levels. Elevated maternal homocysteine has been associated with an increased incidence of birth defects, such as neural tube defect, spontaneous abortions and low birth weight babies. 


\section{Table 3 - Some research articles showing association of choline with developmental disorder mitigation in various test systems}

\begin{tabular}{|c|c|c|c|}
\hline SI. no. & $\begin{array}{l}\text { Test system/ } \\
\text { Subjects }\end{array}$ & Observed effects & References \\
\hline 1. & $\begin{array}{l}\text { Population based } \\
\text { control study } \\
\text { in human }\end{array}$ & $\begin{array}{l}\text { Periconceptional intake of choline may contribute } \\
\text { to reduced risk of orofacial clefts. }\end{array}$ & $\begin{array}{l}\text { Shaw et al. } \\
(2006)\end{array}$ \\
\hline 2. & $\begin{array}{l}\text { Sprague-Dawley } \\
\text { rats }\end{array}$ & $\begin{array}{l}\text { Choline availability during pregnancy has an enduring } \\
\text { impact on hippocampal neurogenesis of the offspring } \\
\text { i.e. prenatally choline supplemented animals showed } \\
\text { increased adult neurogenesis. }\end{array}$ & $\begin{array}{l}\text { Glenn et al. } \\
(2007)\end{array}$ \\
\hline 3. & Mouse models & $\begin{array}{l}\text { Prenatal or postnatal choline supplementation } \\
\text { attenuates the motor coordination deficits } \\
\text { and improves neuronal integrity, proliferation } \\
\text { and survival in Rett syndrome. }\end{array}$ & $\begin{array}{l}\text { Nag et al. } \\
(2008), \text { Ward } \\
\text { et al. (2009) }\end{array}$ \\
\hline 4. & $\begin{array}{l}\text { In vivo (Sprague- } \\
\text { Dawley rats) }\end{array}$ & $\begin{array}{l}\text { Nutritional supplementation with choline in rats } \\
\text { exposed to ethanol in utero almost completely } \\
\text { mitigates the degenerative effects of ethanol on } \\
\text { development and behavior. Further, the therapeutic } \\
\text { window of choline, being quite large, can effectively } \\
\text { attenuate ethanol's teratogenic effects whether } \\
\text { administered during prenatal ethanol exposure } \\
\text { or after the alcohol insult is complete. }\end{array}$ & $\begin{array}{l}\text { Thomas et al. } \\
(2009,2010)\end{array}$ \\
\hline 5. & Human & $\begin{array}{l}\text { Supplementation of choline to mothers may mitigate } \\
\text { the effects of the alcohol and reduce the severity } \\
\text { or prevalence of FAS. }\end{array}$ & $\begin{array}{l}\text { Ballard et al. } \\
(2012)\end{array}$ \\
\hline
\end{tabular}

Choline as antioxidant

An undisturbed choline transport and distribution throughout the body essentially plays a vital role in multiple clinical manifestations. The methyl donation function of choline is of major importance in maintaining balanced cellular antioxidant defence systems thereby checking oxidative stress and apoptosis (Table 4). A recent review (Corbin and Zeisel, 2012) sites a battery of works which attempts to establish the intricate connection between choline deficiency and development of non-alcoholic fatty liver disease (NAFLD) which may ultimately progress to hepatocarcinogenesis. Studies in human as well as in mouse, confirm that a deletion of choline-related genes, alteration of mitochondrial membrane composition owing to choline deficiency, chronic endoplasmic reticulum stress, levels of gut microbiome modulating the availability of choline may enhance the fatty liver disease.

\section{Discussion and Conclusion}

The recognition to choline as an essential nutrient is not a new concept. In the past choline has been recognized as an essential nutrient as being biologically 
Table 4 - List of some recent studies on antioxidative role of choline

\begin{tabular}{|c|c|c|c|}
\hline SI. no. & $\begin{array}{l}\text { Test system/ } \\
\text { Subjects }\end{array}$ & Observed effects & References \\
\hline 1. & $\begin{array}{l}\text { Weanling Wistar } \\
\text { male rats }\end{array}$ & $\begin{array}{l}\text { Choline deficiency produces oxidative damage in the } \\
\text { liver, heart, kidney, and brain, with an increased lipid } \\
\text { peroxidation of subcellular organelles and a decrease } \\
\text { in tissue antioxidants. }\end{array}$ & $\begin{array}{l}\text { Ossani et al. } \\
(2007)\end{array}$ \\
\hline 2. & $\begin{array}{l}\text { Male Fisher } \\
344 \text { rats }\end{array}$ & $\begin{array}{l}\text { Chronic methyl group deficiency due to low levels } \\
\text { of dietary choline leads to an imbalance in cellular } \\
\text { antioxidant defence systems, increased oxidative } \\
\text { stress, and apoptosis. }\end{array}$ & $\begin{array}{l}\text { Bagnyukova } \\
\text { et al. (2008) }\end{array}$ \\
\hline 3. & $\begin{array}{l}\text { Male Swiss } \\
\text { mice }\end{array}$ & $\begin{array}{l}\text { Folate deprivation and radiation interact to mobilize } \\
\text { additional choline reserves of hepatic tissue for } \\
\text { redistribution to other organs, which could not be } \\
\text { utilized by folate deficiency alone and thereafter } \\
\text { trigger utilization of choline as substitute for selected } \\
\text { one-carbon transfer reactions. }\end{array}$ & $\begin{array}{l}\text { Batra et al. } \\
(2009)\end{array}$ \\
\hline 4. & $\begin{array}{l}\text { Weanling male } \\
\text { Wistar rats }\end{array}$ & $\begin{array}{l}\text { Decreased antioxidant content and increased lipid } \\
\text { peroxidation are earlier biochemical alterations that } \\
\text { precede and lead to histological cell death by necrosis } \\
\text { in choline deficiency. }\end{array}$ & $\begin{array}{l}\text { Repetto et al. } \\
\text { (2010) }\end{array}$ \\
\hline 5. & $\begin{array}{l}\text { Rodent model } \\
\text { (C57BL/6J wild- } \\
\text { type mice) }\end{array}$ & $\begin{array}{l}\text { Adverse effects of choline deficiency on hepatic } \\
\text { mitochondrial structure and function could be linked } \\
\text { to the unique signature of hepatic lipid accumulation, } \\
\text { inflammation, and cellular and mitochondrial injury } \\
\text { induced in mice maintained on a very high fat, } \\
\text { protein-restricted, very low carbohydrate and } \\
\text { ketogenic diet. }\end{array}$ & $\begin{array}{l}\text { Schugar et al. } \\
\text { (2013) }\end{array}$ \\
\hline
\end{tabular}

important, without a complete understanding about the underlying reasons. The earlier recognition was not backed up by studied evidence about its precise functions in the various complex biological processes. But there is a vital difference in the approach to the recognition following newer findings. The recent studies provide a clear insight into the molecular basis of various roles played by choline and its metabolites, leading to better understanding about the functions of these substances in health and disease development and control processes. This understanding based on the recent findings establishes choline as a vital component of our diet requirement and opens up newer areas of knowledge, ways in which many physiological conditions take place and the role played by choline in these processes. The understanding offers a clue into the mechanisms associated with diseases like Alzheimer's, non-alcoholic fatty liver disease, fetal alcohol syndrome and neural tube defects with the prospect to control, minimize and even to cure them. 


\section{References}

Bagnyukova, T.V., Powell, C. L., Pavliv, O., Tryndyak, V. P., Pogribny, I. P. (2008) Induction of oxidative stress and DNA damage in rat brain by a folate/methyl-deficient diet. Brain Res. 1237, 44-51.

Ballard, M. S., Sun, M., Ko, J. (2012) Vitamin A, folate, and choline as a possible preventive intervention to fetal alcohol syndrome. Med. Hypotheses 78, 489-493.

Batra, V., Paul, T., Devasagayam, A. (2009) Interaction between cytotoxic effects of radiation and folate deficiency in relation to choline reserves. Toxicology 255, 91-99.

Blusztajn, J. K., Zeisel, S. H., Wurtman, R. J. (1985) Developmental changes in the activity of phosphatidylethanolamine $\mathrm{N}$-methyltransferases in rat brain. Biochem. J. 232, 505-511.

Cheng, W.-L., Holmes-Mc Nary, M. Q., Mar, M.-H., Lien, E. L., Zeisel, S. H. (1996) Bioavailability of choline and choline esters from milk in rat pups. J. Nutr. Biochem. 7, 457-464.

Cohen, E. L., Wurtman, R. J. (1975) Brain acetylcholine: increase after systemic choline administration. Life Sci. 16(7), 1095-1102.

Corbin, K. D., Zeisel, S. H. (2012) Choline metabolism provides novel insights into non-alcoholic fatty liver disease and its progression. Curr. Opin. Gastroenterol. 28(2), 159-165.

Craciunescu, C. N., Albright, C. D., Mar, M. H., Song, J., Zeisel, S. H. (2003) Choline availability during embryonic development alters progenitor cell mitosis in developing mouse hippocampus. J. Nutr. 133(11), 3614-3618.

da Costa, K. A., Kozyreva, O. G., Song, J., Galanko, J. A., Fischer, L. M., Zeisel, S. H. (2006) Common genetic polymorphisms affect the human requirement for the nutrient choline. FASEB J. 20, 1336-1344.

FitzGerald, J., Moureau, S., Drogaris, P., O’Connell, E., Abshiru, N., Verreault, A., Thibault, P., Grenon, M., Lowndes, N. F. (2011) Regulation of the DNA damage response and gene expression by the Dot1L histone methyltransferase and the 53Bp1 tumour suppressor. PLoS One 6(2), e14714.

Food and Nutrition Board (Institute of Medicine) (1998) Dietary Reference Intakes for Folate, Thiamin, Riboflavin, Niacin, Vitamin B12, Pantothenic Acid, Biotin and Choline. National Academy Press, Washington, D.C.

Fu, A. L., Li, Q., Dong, Z. H., Huang, S. J., Wang, Y. X., Sun, M. J. (2004) Alternative therapy of Alzheimer's disease via supplementation with choline acetyltransferase. Neurosci. Lett. 368, 258-262.

Garner, S. C., Mar, M. H., Zeisel, S. H. (1995) Choline distribution and metabolism in pregnant rats and fetuses are influenced by the choline content of the maternal diet. J. Nutr. 125(11), 2851-2858.

Glenn, M. J., Gibson, E. M., Kirby, E. D., Mellott, T. J., Blusztajn, J. K., Williams, C. L. (2007) Prenatal choline availability modulates hippocampal neurogenesis and neurogenic responses to enriching experiences in adult female rats. Eur. J. Neurosci. 25(8), 2473-2482.

Glenn, M. J., Adams, R. S., McClurg, L. (2012) Supplemental dietary choline during development exerts antidepressant-like effects in adult female rats. Brain Res. 1443, 52-63.

Haubrich, D. R., Wedeking, P.W., Wang, P. F. (1974) Increase in tissue concentration of acetylcholine in guinea pigs in vivo induced by administration of choline. Life Sci. 14(5), 921-927.

Jensen, H. H., Batres-Marquez, S. P., Carriquiry, A., Schalinske, K. L. (2007) Choline in the diets of the U.S. population: NHANES, 2003-2004. FASEB J. 21, Ib219.

Le Kim, D., Betzing, H. (1976) Intestinal absorption of polyunsaturated phosphatidyl-choline in the rat. Hoppe Seylers Z. Physiol. Chem. 357, 1321-1331.

Li, Q., Guo-Ross, S., Lewis, D.V., Turner, D., White, A. M., Wilson, W. A., Swartzwelder, H. S. (2004) Dietary prenatal choline supplementation alters postnatal hippocampal structure and function. J. Neurophysiol. 191, 1545-1555.

Li, Z., Vance, D. (2008) Phosphatidylcholine and choline homeostasis. J. Lipid Res. 49, 1187-1194.

Loughery, J. E., Dunne, P. D., O'Neill, K. M., Meehan, R. R., McDaid, J. R., Walsh, C. P. (2011) DNMT1 deficiency 
triggers mismatch repair defects in human cells through depletion of repair protein levels in a process involving the DNA damage response. Hum. Mol. Genet. 20, 3241-3255.

LSRO/FASEB (Life Sciences Research Office/Federation of American Societies for Experimental Biology)

(1981) Effects of consumption of choline and lecithin on neurological and cardiovascular systems. Report PB-82-133257.

Meck, W. H.,Williams, C. L. (2003) Metabolic imprinting of choline by its availability during gestation: Implications for memory and attentional processing across the lifespan. Neurosci. Biobehav. Rev. 27, 385-399.

Mellott, T. J., Follettie, M.T., DiesI, V., Hill, A. A., Lopez-Coviella, I., Blusztago, J. K. (2007) Prenatal choline availability modulated hippocampal and cerebral cortical gene expression. FASEB J. 21, 1311-1323.

Nag, N., Mellott, T. J., Berger-Sweeney, J. E. (2008) Effects of postnatal dietary choline supplementation on motor regional brain volume and growth factor expression in a mouse model of Rett syndrome. Brain Res. 1237, 101-109.

Nitsch, R. M., Blusztajn, J. K., Pittas, A. G., Slack, B. E., Growdon, J. H., Wurtman, R. J. (1992) Evidence for a membrane defect in Alzheimer disease brain. Proc. Natl. Acad. Sci. U. S. A. 89, 1671-1675.

Ossani, G., Dalgh, M., Repetto, M. (2007) Oxidative damage lipid peroxidation in the kidney of cholinedeficient rats. Front. Biosci. 12, 1174-1183.

Pogribny, I. P., Shpyleva, S. I., Muskhelishvili, L., Bagnyukova, T.V., James, S. J., Beland, F. A. (2009) Role of DNA damage and alterations in cytosine DNA methylation in rat liver carcinogenesis induced by a methyldeficient diet. Mutat. Res. 669, 56-62.

Powell, C. L., Kosyk, O., Bradford, B. U., Parker, J. S., Lobenhofer, E. K., Denda, A., Uematsu, F., Nakae, D., Rusyn, L. (2005) Temporal correlation of pathology and DNA damage with gene expression in a cholinedeficient model of rat liver injury. Hepatology 42, 1137-1147.

Repetto, M. G., Ossani, G., Monserrat, A. J., Boveris, A. (2010) Oxidative damage:The biochemical mechanism of cellular injury and necrosis in choline deficiency. Exp. Mol. Pathol. 88, 143-149.

Resseguie, M., Song, J., Niculescu, M. D., da Costa, K. A., Randall, T. A., Zeisel, S. H. (2007) Phosphatidylethanolamine $\mathrm{N}$-methyltransferase (PEMT) gene expression is induced by estrogen in human and mouse primary hepatocytes. FASEB J. 21, 2622-2632.

Resseguie, M. E., da Costa, K. A., Galanko, J. A., Patel, M., Davis, I. J., Zeisel, S. H. (2011) Aberrant estrogen regulation of PEMT results in choline deficiency-associated liver dysfunction.J. Biol. Chem. 286, 1649-1658.

Schugar, R. C., Huang, X., Moll, A. R., Brunt, E. M., Crawford, P.A. (2013) Role of choline deficiency in the fatty liver phenotype of mice fed a low protein, very low carbohydrate ketogenic diet. PLoS One 8(8), e74806.

Shaw, G. M., Carmichael, S. L., Yang, W., Selvin, S., Schaffer, D. M. (2004) Periconceptional dietary intake of choline and betaine and neural tube defects in offspring. Am. J. Epidemiol. 160, 102-109.

Shaw, G. M., Carmichael, S. L., Laurent, C., Rasmussen, S. A. (2006) Maternal nutrient intakes and risk of orofacial clefts. Epidemiology 17, 285-291.

Shinohara, Y., Hasegawa, H., Ogawa, K., Tagoku, K., Hashimoto, T. (2006) Distinct effects of folate and choline deficiency on plasma kinetics of methionine and homocysteine in rats. Metabolism 55, 899-906.

Shronts, E. P. (1997) Essential nature of choline with implications for total parental nutrition. J.Am. Diet. Assoc. 97(6), 639-646, 649.

Song, G., Cui, Y., Han, Z. J., Xia, H. F., Ma, X. (2012) Effects of choline on sodium arsenite-induced neural tube defects in chick embryos. Food Chem. Toxicol. 50(12), 4364-4374.

Stevens, K. E., Adams, C. E., Mellott, T. J., Robbins, E., Kisley, M. A. (2008) Perinatal choline deficiency produces abnormal sensory inhibition in Sprague-Dawley rats. Brain Res. 1237, 84-90. 
Thomas, J. D., Abou, E. J., Dominguez, H. D. (2009) Prenatal choline supplementation mitigates the adverse effects of prenatal alcohol exposure on development in rats. Neurotoxicol. Teratol. 31(5), 303-311.

Thomas, J. D., Idrus, N. M., Monk, B. R., Dominguez, H. D. (2010) Prenatal choline supplementation mitigates behavioral alterations associated with prenatal alcohol exposure in rats. Birth Defects Res. A Clin. Mol. Teratol. 88(10), 827-837.

Ward, B. C., Kolodny, N. H., Nag, N., Berger-Sweeney, J. E. (2009) Neurochemical changes in a mouse model of Rett syndrome: Changes over time and in response to perinatal choline nutritional supplementation. J. Neurochem. 108, 361-371.

Wecker, L. (1986) Neurochemical effects of choline supplementation. Can. J. Physiol. Pharmacol. 64(3), 329-333.

Zeisel, S. H. (2006a) Choline: Critical role during fetal development and dietary requirements in adults. Annu. Rev. Nutr. 26, 229-250.

Zeisel, S. H. (2006b) The fetal origins of memory: The role of dietary choline in optimal brain development. J. Pediatr. 149, S131-S136.

Zeisel, S. H. (2012) Dietary choline deficiency causes DNA strand breaks and alters epigenetic marks on DNA and histones. Mutat. Res. 733, 34-38.

Zeisel, S. H., Blusztajn, J. K. (1994) Choline and human nutrition. Annu. Rev. Nutr. 14, 269-296.

Zeisel, S. H., da Costa, K. A. (2009) Choline: An essential nutrient for public health. Nutr. Rev. 67(11), 615-623.

Zeisel, S. H., Char, D., Sheard, N. F. (1986) Choline, phosphatidylcholine and sphingomyelin in human and bovine milk and infant formulas. J. Nutr. 116, 50-58.

Zeisel, S. H., Mar, M. H., Howe, J., Holden, J. (2003) Concentrations of choline-containing compounds and betaine in common foods. J. Nutr. 133, 1302-1307. 